\title{
APLIKASI BIOFLOK DAN PROBIOTIK DALAM PAKAN PADA PEMBESARAN IKAN LELE MUTIARA (Clarias gariepinus)
}

\author{
Madyasta Anggana Rarassaria ${ }^{a}$, Sefti Heza Dwinanti ${ }^{b}$, Feldya D. Absharina ${ }^{b}$, Zellica Gevira $^{b}$

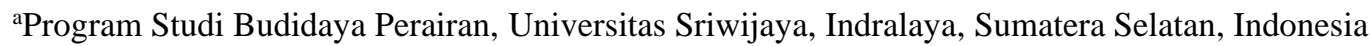 \\ brogram Studi Budidaya Perairan, Universitas Sriwijaya, Indralaya, Sumatera Selatan, Indonesia
}

*Koresponden penulis: madyastaangganararassari@unsri.ac.id

\begin{abstract}
Abstrak
Pakan merupakan faktor penting dalam keberhasilan budidaya, pakan juga menjadi komponen yang menghabiskan biaya terbesar yaitu sekitar $70 \%$ dari total biaya produksi. Untuk itu perlu dilakukan teknik yang bisa meningkatkan produksi, salah satunya dengan dilakukan peningkatan nutrisi pakan menggunakan probiotik EM4. Selain itu, bisa juga dengan menerapkan teknologi bioflok yang memanfaatkan bakteri yang bisa mengolah limbah budidaya yang merupakan masalah pada kualitas air menjadi sumber pakan ikan yang tersedia secara menerus. Penelitian ini bertujuan untuk mengetahui apakah pengaplikasian dari teknologi bioflok dan pakan dengan EM4 bisa meningkatkan produksi budidaya. Ada 3 perlakuan yang akan digunakan yaitu, P1 (aplikasi bioflok), P2 (aplikasi EM4), P3 (tanpa bioflok dan EM4). Ikan yang digunakan yaitu benih ikan lele mutiara (Clarias gariepinus) dengan ukuran $6,5 \pm 0,5 \mathrm{~cm}$ dengan padat tebar 150 ekor $/ \mathrm{m}^{3}$. Pemeliharaan dilakukan selama 30 hari (1 bulan) dengan frekuensi pemberian pakan dua kali sehari sebanyak 3\% dari bobot ikan. Hasil penelitian menunjukkan bahwa pertumbuhan harian ikan didapati P1 6\%, P2 6,6\% dan P3 6\%. Penambahan probiotik untuk pembesaran bisa di aplikasikan untuk budidaya ikan lele dengan menghasilkan pertumbuhan harian 6-6,6\% lalu panjang mutlak 8,4-8,7 cm, bobot mutlak 25-27 g dan FCR 1,23-1,28.
\end{abstract}

Kata kunci: Bioflok, Ikan Lele, Pakan, Pembesaran, Probiotik.

\begin{abstract}
Feed is an important factor in the success of cultivation, feed is also the component that costs the most that is about $70 \%$ of the total production cost. Therefore, it is necessary to do techniques that can increase production, one of which is by improving feed nutrition using EM4 probiotics. In addition, it can also be by applying bioflok technology that utilizes bacteria that can process aquaculture waste which is a problem in water quality into a continuously available source of fish feed. This study aims to find out if the application of bioflok and feed technology with EM4 can increase cultivation production. There are 3 treatments that will be used, namely, P1 (bioflok application), P2 (EM4 application), P3 (without bioflok and EM4). The fish used is pearl catfish seed (Clarias gariepinus) with a size of $6.5 \pm 0.5 \mathrm{~cm}$ with a dense spread of 150 heads / $\mathrm{m} 3$. Maintenance was carried out for 30 days (1 month) with a frequency of feeding twice a day as much as $3 \%$ of the weight of the fish. The results showed that the daily growth of fish was found to be P1 $6 \%, \mathrm{P} 26.6 \%$ and P3 6\%. The addition of probiotics for enlargement can be applied to catfish culture by producing a daily growth of 6-6.6\% then an absolute length of 8.4-8.7 cm, an absolute weight of 25-27 $\mathrm{g}$ and an FCR of 1.23-1.28.
\end{abstract}

Keywords: Biofloc, Clarias gariepinus, Enlargement, Feed, Probiotic

\section{PENDAHULUAN}

Ikan lele merupakan salah satu jenis ikan konsumsi dari berbagai banyak ikan konsumsi yang hidup di air tawar. Untuk membudidayakan ikan lele ini sangatlah mudah selain itu juga ikan lele memiliki waktu panen yang singkat, sehingga tak sedikit petani ikan yang membudidayakannya [1]. Ikan lele juga kaya akan manfaat seperti rendah kalori dan lemak, mempunyai sumber protein yang lengkap, sebagai sumber vitamin B-12, rendah akan merkuri, dan juga mengandung asam lemak yang sehat serta harga yang terjangkau sehingga ikan lele memiliki pasarnya sendiri. 
Penentu keberhasilan dalam suatu usaha budidaya ikan, salah satunya adalah dapat mempercepat pertumbuhannya, sehingga dapat meningkatkan nilai produksi pada ikan itu sendiri. Faktor penting dalam mendukung usaha tersebut salah satunya adalah pakan dikarenakan $60-70 \%$ dari total biaya produksi itu berasal dari pakan. Pakan yang mudah dicerna dengan baik oleh ikan akan meningkatkan pertumbuhan ikan itu sendiri, sehingga energi yang diperoleh dari pakan tersebut dapat dimanfaatkan secara optimum. Di dalam tubuh ikan terdapat enzim pencernaan yang berfungsi untuk meningkatkan daya cerna terhadap pakan dan juga dapat memacu pertumbuhannya [2][3].

Berbagai macam usaha telah dilakukan petani untuk menekan biaya pakan salah satunya dengan cara penambahan probiotik ke dalam pakan ataupun pada airnya dan lingkungan hidup ikan lele itu sendiri.

Probiotik merupakan mikroba hidup dalam bentuk kultur tunggal maupun campuran, yang apabila ditambahkan ke dalam pakan akan memberikan manfaat yang menguntungkan inang dengan menjaga mikroba pada ususnya [4], Salah satu produk probiotik yang sering digunakan dalam dunia perikanan adalah $\mathrm{EM}_{4} \quad$ (Effective Microorganisms 4).

Teknologi Bioflok diadopsi dari proses pengolahan air limbah secara biologis (biological wastewater treatment). Teknik ini mencoba memproses limbah budidaya secara langsung di dalam petak budidaya dengan mempertahankan kecukupan oksigen, mikroorganisme, dan rasio $\mathrm{C} / \mathrm{N}$ dalam tingkat tertentu. Salah satu probiotik yang dapat membentuk bioflok adalah Bacillus sp [5]. Probiotik berperan positif pada organisme yang dibudidayakan diantaranya meningkatkan pertumbuhan, sintasan, daya cerna, sistem kekebalan dan kualitas air melalui proses bioremediasi [6]. Teknologi bioflok menjadi salah satu alternatif pemecah masalah limbah budidaya intensif, teknologi ini yang paling menguntungkan karena selain dapat menurunkan limbah nitrogen anorganik dari sisa pakan dan kotoran, teknologi ini juga dapat menyediakan pakan tambahan berprotein untuk hewan budidaya sehingga dapat menaikkan pertumbuhan dan efisiensi pakan.

\section{METODE}

Alat-alat yang digunakan pada penelitian ini adalah 2 buah kolam bundar dengan diameter 3 meter, kertas $\mathrm{pH}$, termometer, mistar, timbangan analitik, skop net, ember, aerator. Bahan-bahan yang digunakan pada penelitian ini yaitu ikan lele mutiara ukuran 7$8 \mathrm{~cm}$, Effective Microorganism $\left(\mathrm{EM}_{4}\right)$, probiotik, air, molase, garam, kapur, dan pakan.

\section{Rancangan Penelitian}

Penelitian ini dilakukan dengan menggunakan metode eksperimen perbandingan yaitu :

Perlakuan 1 : aplikasi bioflok $15 \mathrm{ml} / \mathrm{L}$,

Perlakuan 2 : aplikasi probiotik $15 \mathrm{ml} / \mathrm{L}$

Perlakuan 3 : tanpa bioflok dan probiotik.

Adapun parameter yang diamati pada penelitian ini yaitu kelangsungan hidup, laju pertumbuhan spesifik, pertumbuhan bobot mutlak, pertumbuhan panjang mutlak, rasio konversi pakan dan volume flok, serta kualitas air berupa suhu, $\mathrm{pH}$, dan DO.

\section{Prosedur Penelitian}

\section{Persiapan Kolam Pemeliharaan}

Sebelum dilakukan pemeliharaan, kolam terlebih dahulu disterilkan untuk menghindari organisme lain berupa hama, baru setelah itu kolam diisi air dengan volume $5 \mathrm{~m}^{3}$ atau setara dengan ketinggian air $70 \mathrm{~cm}$.

\section{Penambahan Probiotik $\left(E_{4}\right)$ pada Pakan Pellet}

Pencampuran probiotik dalam pakan dilakukan dengan cara penyemprotan secara merata dalam pakan menggunakan botol spray. Untuk $1 \mathrm{~kg}$ pakan dibutuhkan probiotik sebanyak 15 ml. Namun sebelum disemprotkan ke pakan, probiotik $\left(\mathrm{EM}_{4}\right)$ dicairkan terlebih dahulu dengan dicampurkan akuades sebanyak $50 \mathrm{ml}$ [7]. Setelah itu, dimasukkan ke dalam botol spayer untuk disemprotkan ke pada pakan. Kemudian 
difermentasikan dengan menginkubasi pada suhu kamar selama 24 jam. Penambahan probiotik dilakukan pada awal sebelum pemeliharaan, pakan yang ditambah probiotik di awal adalah $1 \mathrm{~kg}$. Pakan tersebut diberikan untuk pemeliharaan ikan perlakuan.

\section{Pembuatan Probiotik}

Persiapan media dilakukan untuk menstimulasi pembentukan flok-flok oleh bakteri heterotrof dan simbionnya dengan bantuan sumber karbon. Persiapan media terdiri dari beberapa tahapan yang berurutan, yaitu penambahan garam 1000 g.m ${ }^{-3}$, penambahan kapur 100 g.m. $\mathrm{m}^{-3}$, penambahan molase $100 \mathrm{~mL} \cdot \mathrm{m}^{-3}$, dan penambahan probiotik (EM4) 100 mL.m ${ }^{-3}$. Kemudian Wadah pemeliharaan didiamkan kembali selama 5-7 hari agar bakteri dapat berkembang biak sehingga dapat membentuk flok dalam air. Bioflok akan terbentuk bila ditandai dengan munculnya gumpalan gumpalan kecil baik yang menempel pada wadah maupun melayang dalam air dan juga terdapat buih pada permukaan air

\section{Pemeliharan Ikan}

Padat tebar benih ikan lele yang digunakan adalah 1000 ekor.m ${ }^{-2}$. Sebelum benih ikan lele ditebar, dilakukan aklimatisasi terlebih dahulu untuk menghindari stres pada benih ikan lele, selain itu juga dilakukan perhitungan Panjang dan bobot ikan. Proses aklimatisasi dilakukan dengan cara mengapungkan kantong plastik berisi benih ikan lele selama 15 menit kemudian kantong plastik dimiringkan sampai benih ikan lele keluar dengan sendirinya[4]. Kemudian dilakukan sampling awal sebelum pemeliharaan. Pemeliharaan ikan lele dilakukan selama 30 hari mulai dari penebaran benih. Pada bioflok dilakukan penambahan molase $50 \mathrm{ml} / \mathrm{m} 2$ dan probiotik $50 \mathrm{ml} / \mathrm{m} 2$ ke media air pemeliharaan dilakukan sebnyak 1 minggu sekali. Tujuan dari penambahan tersebut agar mampu menjaga stabilitas populasi bakteri pembentuk floc. Frekuensi pemberian pakan ikan lele sebanyak 2 kali dalam sehari yaitu pada pukul 08.00 dan 16.00 WIB dengan jumlah pemberian pakan $3 \%$ dari bobot tubuh [4].
Sampling dilakukan dalam 14 hari sekali dan apabila terdapat ikan yang mati diukur bobot dan panjangnya.

\section{Analisis Data}

Tingkat kelangsungan hidup dihitung dengan rumus :

$\mathrm{SR}=\frac{N t}{N n} \times 100 \%$

Keterangan:

$\mathrm{SR}=$ Survival Rate $(\%)$

$\mathrm{Nt}=$ Jumlah ikan yang hidup pada akhir pemeliharaan (ekor)

No $=$ Jumlah ikan pada awal pemeliharaan (ekor).

Laju pertumbuhan spesifik dihitung dengan rumus :

$\mathrm{SGR}=(\underline{\mathrm{Wt}}-\mathrm{Wo}) \times 100 \%$

Keterangan:

SGR = Laju pertumbuhan spesifik (\%)

$\mathrm{Wt}=$ Bobot ikan akhir $(\mathrm{g})$

Wo = Bobot ikan uji awal (g)

$\mathrm{t} \quad=$ Lama waktu pemeliharaan (hari)

Pertumbuhan bobot mutlak dihitung dengan menggunakan rumus:

$\mathrm{W}=\mathrm{Wt}-\mathrm{Wo}$

Keterangan :

$\mathrm{W}=$ Pertumbuhan bobot mutlak ikan $(\mathrm{g})$

$\mathrm{Wt}=$ Bobot ikan pada akhir pemeliharaan ( $\mathrm{g})$

Wo = Bobot ikan pada awal pemeliharaan (g)

Pertumbuhan panjang mutlak dihitung dengan menggunakan rumus:

$\mathrm{L}=\mathrm{Lt}-\mathrm{Lo}$

Keterangan :

$\mathrm{L}=$ Pertumbuhan panjang mutlak ikan (cm)

Lt = Panjang ikan pada akhir pemeliharaan $(\mathrm{cm})$

Lo $=$ Panjang ikan pada awal pemeliharaan (cm)

Rasio konversi pakan dihitung dengan rumus :

$F C R=\frac{F}{(W t+D)-W c}$

Keterangan :

FCR $=$ Feed Conversion Ratio 

$\mathrm{Wt}=$ Bobot total ikan di akhir pemeliharaan $(\mathrm{g})$
$\mathrm{D}=$ Bobot total ikan mati saat pemeliharaan $(\mathrm{g})$
Wo $=$ Bobot total ikan di awal pemeliharaan (g)
$\mathrm{F} \quad=$ Jumlah total pakan yang dikonsumsi (g) rumus:

Pengukuran volume flok dihitung dengan

Volume flok $\left(\frac{\mathrm{mI}}{\mathrm{L}}\right)=\frac{\text { Flok yang mengendap (ml)! }}{\text { Sampel air yang diambil (LL) }}$

Data yang diperoleh dibuat dalam bentuk tabel dan grafik, data tersebut akan di analisis dengan analysis of variance (ANOVA) dan apabila menunjukkan $\mathrm{F}_{\text {hitung }}>\mathrm{F}_{\text {tabel }}$ (berbeda nyata), maka selanjutnya dilakukan uji perbandingan (Uji T).

\section{HASIL DAN PEMBAHASAN}

Pembuatan probiotik dengan memanfaatkan bahan-bahan lokal yaitu ragi tape, ragi roti, yakult, buah pisang dan nanas sebagai sumber karbohidrat bagi bakteri.

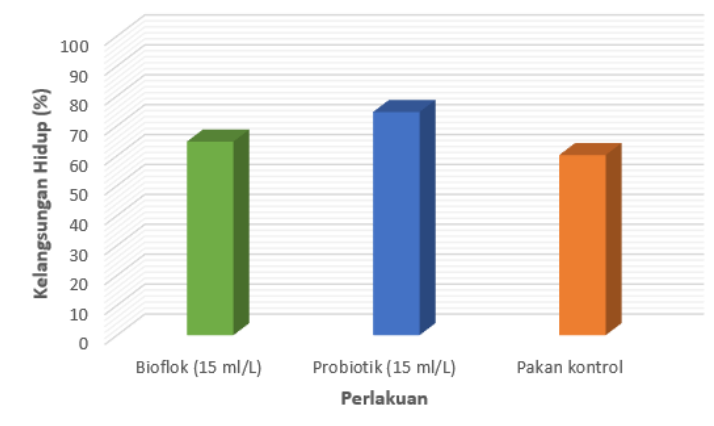

Gambar 1. Kelangsungan Hidup Ikan (\%)

Data kelangsungan hidup ikan lele yang diperoleh pada teknologi bioflok yaitu sebesar $64,7 \%$ menunjukkan nilai yang lebih rendah jika dibandingkan dengan pemberian probiotik. Bakteri dalam probiotik dapat lebih berperan dalam pengontrolan bakteri pathogen dengan meningkatkan imun ikan sehingga ikan dapat lebih bisa bertahan dalam kondisi cuaca yang tidak mendukung, intensitas hujan yang sangat deras di setiap harinya membuat fluktuasi yang tidak beraturan pada $\mathrm{pH}$ dan suhu air, sehingga dalam keadaan ekstrem ini ikan yang dapat bertahan hanya sekitar setengah dari total awal ditebar. Mati listrik hampir setiap hari juga membuat aerator yang digunakan untuk memenuhi oksigen terlarut pada air berkurang, padat tebar ikan yang cukup tinggi membuat persaingan dalam air pun meninggi yang mengakibatkan ikan mengalami stres akibat kadar oksigen terlarut yang rendah. Sedangkan pada pakan yang ditambahkan EM4 74,6\% karena berada di lokasi yang sama cuaca berikut kondisi listrik mati juga menjadi penyebab rendahnya kelangsungan hidup dari ikan lele. Kemudian, untuk perlakuan 3 kelangsungan hidup yang didapat sebesar $60,2 \%$. Hal ini mengartikan bahwa kualitas air yang baik dan sesuai akan mempengaruhi tingginya kelangsungan hidup ikan [8].

\section{Bobot Mutlak}

Bobot mutlak menunjukkan besarnya pertambahan dari bobot ikan dari awal hingga akhir pemeliharaan adapun bobot mutlak yang dihasilkan dari perlakuan bioflok adalah sebesar 25,7 g dan perlakuan EM4 sebesar 26,91 g. Data ini menjadi selisih antara ratarata bobot awal serta akhir pemeliharaan. Kemudian untuk pertumbuhan panjang mutlak pada ikan perlakuan bioflok ini sebesar $8,7 \mathrm{~cm}$ untuk perlakuan pakan dengan EM4 8,43 cm.

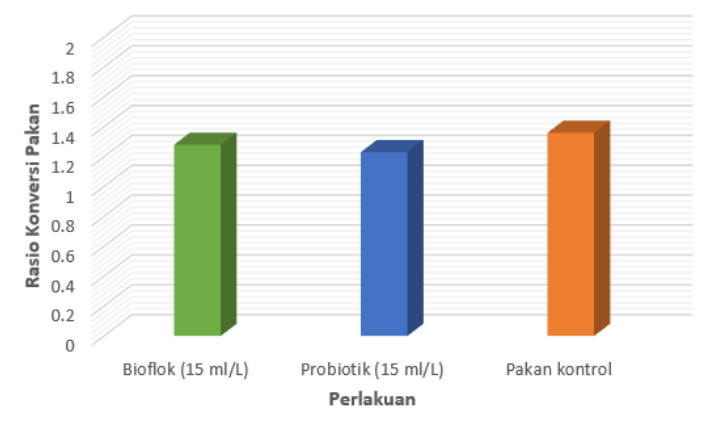

Gambar 2. Rasio Koversi Pakan Ikan

Konversi Pakan (Food Convertion Ratio) merupakan ukuran untuk menyatakan rasio pakan yang dimanfaatkan ikan untuk menghasilkan $1 \mathrm{~kg}$ daging ikan. Semakin kecil nilai konversi pakan maka pakan yang diberikan akan semakin sedikit yang tentu saja akan lebih menghemat biaya pakan, didapatkan hasil 1,28 pada perlakuan bioflok dan 1,23 di perlakuan pakan dengan EM4. 
FCR yang ditunjukkan lebih dari 1 menandakan penyerapan pakan pada ikan masih kurang efektif, meskipun seharusnya dengan teknologi bioflok dan penambahan EM4 pada pakan bertujuan untuk meningkatkan efisiensi pemanfaatan pakan pada ikan. Nilai Food Convertion Ratio (FCR) yang cukup baik berkisar antara 0,8 - 1,6. Artinya, 1 kilogram nila konsumsi dihasilkan dari $0,8-1,6 \mathrm{~kg}$ pakan. Nilai konversi pakan yang rendah berarti kualitas pakan yang diberikan baik. Sedangkan bila nilai konversi pakan tinggi berarti kualitas pakan yang diberikan kurang baik. Semakin rendah nilai rasio pakan, maka kualitas pakan yang diberikan semakin baik [9], [11]. Hal ini menunjukkan bahwa dengan adanya penambahan probiotik, ikan dapat memanfaatkan pakan yang diberikan secara optimal dibandingkan dengan pakan tanpa pemberian probiotik

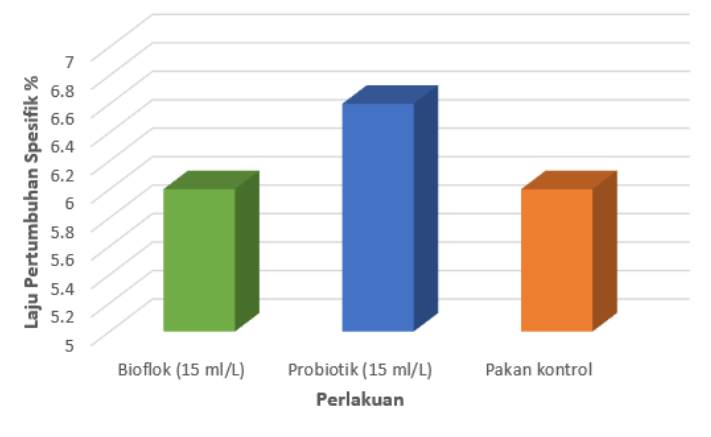

Gambar 3. Laju Pertumbuhan Spesifik (\%)

Spesific Growh Ratio atau konversi pertumbuhan spesifik adalah persentase dari pertumbuhan per hari yang diperoleh ikan, adapun hasil SGR adalah sebesar $6 \%$ pada P1 dan 6,6\% pada P2 dan P3 sebesar 6\%. Pemberian probiotik EM4 mempengaruhi laju pertumbuhan spesifik dan FCR dari ikan lele, jumlah pakan yang dikonsumsi akan secara langsung berpengaruh terhadap pertumbuhan ikan [9]. Dengan adanya bakteri probiotik dalam pakan yang kemudian masuk ke dalam saluran pencernaan, mampu menekan bakteri patogen yang terdapat dalam usus sehingga membantu pencernaan pakan lebih cepat.

Hasil yang berbeda didapatkan pada perlakukan P1 dan P3. Bakteri tersebut akan menghidrolisis protein menjadi senyawa yang lebih sederhana sehingga mudah diserap oleh tubuh. Bakteri probiotik pada pakan mampu menghasilkan enzim-enzim yang berfungsi sebagai pemecah nutrien sehingga mengoptimalkan penyerapan nutrien pakan pada saluran pencernaan [8].

\section{Kualitas Air}

Data kualitas air yang diperoleh berdasarkan tabel yaitu untuk suhu berkisar 25-30 ${ }^{\circ} \mathrm{C}, \mathrm{pH}$ 6-7 dan Oksigen terlarut (DO) 3,4 . Kondisi kualitas air pada saat pemeliharaan berbasis teknologi bioflok masih optimal untuk mendukung pertumbuhan lele, air pada kolam tidak pernah diganti hingga akhir pemeliharaan, sedangkan pada pemeliharaan dengan pemberian pakan dengan EM4 dilakukan penggantian air sebanyak 2 kali dan didapatkan hasil dengan data suhu $25-30^{\circ} \mathrm{C}$, pH 6-7 dan oksigen terlarut (DO) 3,3. Jika dibandingkan dengan [10] kisaran suhu rata-rata yang didapat sama, hanya saja terkadang dalam sehari suhu pada kolam pemeliharaan mengalami fluktuasi karena cuaca yang tidak menentu, untuk alat yang digunakan untuk mengukur suhu ialah termometer yang memungkinkan adanya error sehingga tidak memberikan hasil yang tepat.

Kemudian untuk mengukur $\mathrm{pH}$ digunakan alat ukur $\mathrm{pH}$ universal sehingga kisaran angkanya bulat. Ikan lele mampu mentolerir $\mathrm{pH}$, suhu dan DO di bawah maupun diatas standar yang ditentukan, hanya saja kemungkinan pertumbuhannya akan sedikit terganggu. Pada awal pemeliharaan diduga ukuran ikan yang masih kecil belum bisa beradaptasi dengan baik sehingga ikan stres dan banyak mati sehingga nilai dari kelangsungan hidup ikan kecil.

Table 1. Data kualitas air selama pemeliharaan

\begin{tabular}{llll}
\hline Parameter & \multicolumn{3}{l}{ PERLAKUAN } \\
\cline { 2 - 4 } Kualitas Air & $\mathrm{A}$ & $\mathrm{B}$ & $\mathrm{C}$ \\
\hline Suhu $\left({ }^{\circ} \mathrm{C}\right)$ & $25-30$ & $25-30$ & $25-30$ \\
$\mathrm{pH}$ & $6-7$ & $6-7$ & $6-7$ \\
$\mathrm{DO}(\mathrm{mg} / \mathrm{L})$ & 3,4 & 3,3 & 3,8 \\
\hline
\end{tabular}




\section{KESIMPULAN}

Penambahan probiotik dengan menggunakan EM4 untuk pembesaran bisa di aplikasikan pada budidaya ikan lele dengan menghasilkan pertumbuhan harian 6-6,6\% laju panjang mutlak $8,4-8,7 \mathrm{~cm}$, bobot mutlak 25-27 g dan FCR 1,23-1,28.

\section{DAFTAR PUSTAKA}

[1] Puspitasari, D. 2017. Efektivitas Suplemen Herbal Terhadap Pertumbuhan dan Kelulushidupan Benih Ikan Lele (Clarias sp.). Jurnal Ilman, Vol. 5, No. 1, pp. 53-59, Februari 2017, ISSN 23551488

[2] Arief M., Nur F. dan Sri S. 2014. Pengaruh Pemberian Probiotik Berbeda Pada Pakan Komersial Terhadap Pertumbuhan dan Efisiensi Pakan Ikan Lele Sangkuriang (Clarias Sp.). Jurnal Ilmiah Perikanan dan Kelautan, 6 (1) : 15 hal.

[3] Ahmadi, H., Iskandar dan N. Kurniawati. 2012. Pemberian Probiotik dalam Pakan terhadap Pertumbuhan Lele Sangkuriang (Clarias gariepinus) Pada Pendederan II. Jurnal Perikanan dan Kelautan UNPAD. 3,4 (2012) : 99- 107

. [4] Anugraheni, Pengaruh Penambahan Probiotik Em4 Pada Pakan Ikan Terhadap Pertumbuhan Ikan Nila Merah (Orechromis niloticus), Universitas Sanata Dharma, 2016.

[5] Aiyushirota. 2009. Konsep Budidaya Udang Sistem Bakteri Heterotrof dengan Bioflocs. Dikutif dari e.book dan diakses pada 9 februari 2021.

[6] Gunarto dan Nur Ansari Rangka. 2012. Pengaruh Penumbuhan Bioflok Pada Budidaya Udang Vaname Pola Intensif Di Tambak [The Effect of Biofloc Growing on Vannamei Shrimp Culture At Intensive System Pond]. Jurnal Ilmiah
Perikanan dan

Kelautan.4,2(2012):http://dx.doi.org/10.2 0473/jipk.v4i2.11565

[7] Harmilia, E. D., Helmizuryani dan A, Ahlan. 2019. Pengaruh Dosis Probiotik pada Pakan Kormesil Terhadap Pertumbuhan Ikan Nila Merah (Oreochromis niloticus). Fakultas Pertanian Universitas Muhammadiyah Palembang, Palembang. Fiseries. VIII1:9-13. ISSN: 2301-4172

[8] Primashita, A.H., B. S. Rahardja, D. Manajemen, K. Ikan, and F. Perikanan, "Pengaruh Pemberian Probiotik Berbeda dalam Sistem Akuaponik terhadap Laju Pertumbuhan dan Survival Rate Ikan Lele (Clarias sp.) Effect Addition of Different Probiotic in Aquaponic Systems Towards The Growth Rate and Survival Rate of Catfish (Clarias sp.)," vol. 1, no. April, pp. 1-9, 2017.

[9] Simanjuntak, N. I. Putra, and N. A. Pamukas, "Pengaruh Pemberian Probiotik EM4 pada Pakan Terhadap Pertumbuhan dan Kelulushidupan Benih Ikan Lele Sangkuriang (Clarias sp.) dengan Teknologi Bioflok," $J$. Akuakultur SEBATIN, vol. 1, no. 1, pp. 63-69, 2020.

[10] SNI, "Standar Nasional Indonesia Ikan Lele Dumbo (Clarias sp.) Bagian 4: Produksi Benih.," Sni 01-6484.2-2000, 2014.

[11] Susanti, D,. 2004. Pengaruh Penambahan Berbagai Silase Produk Perikanan dalam Ransum Pakan terhadap Pertumbuhan dan Kelulushidupan Benih Ikan Nila Gift. [Skripsi]. Universitas Diponegoro, $19 \mathrm{hlm}$ 